\title{
Analysis of the competitiveness of rice farming and its implications on Input-Output price policy scenario of rice in Jambi Province - Indonesia
}

\author{
Saad Murdy; Saidin Nainggolan*; Sri Rezeki. R Sihombing \\ Jurusan Agribisnis Fakultas Pertanian Universitas Jambi \\ *Correspondences e-mail: saidinnainggolan@yahoo.com
}

\begin{abstract}
The research objectives are: 1). to analyze the levels of private and social profitability of rice farming, 2). to analyze comparative advantage and competitive advantage rice farming, 3).to analyze the impact of input = output price policy on the competitiveness of rice farming. The study was conducted in rice production centers in the province of Jambi, named Kerinci, Sarolangun, Bungo and Tanjung Jabung Barat determined purposively. The sample size was 314 farmers with methods of Simple Random Sampling. Methods of data analysis used the Policy Analysis Matrix approach (PAM). The results showed that rice farming has high competitiveness. The increase in production input prices does not affect the declining competitiveness. The increase in the price of rice paddy resulted in more and more advantages.
\end{abstract}

Keywords: Competitiveness, Comparative, PAM, Policy scenario

\begin{abstract}
Abstrak
Tujuan penelitian adalah: 1). menganalisis tingkat profitabilitas privat dan sosial usahatani padi, 2). menganalisis keunggulan komparatif dan keunggulan bersaing usahatani padi, 3) menganalisis dampak kebijakan harga input = output terhadap daya saing usahatani padi. Penelitian dilakukan di sentra produksi padi di Provinsi Jambi yang bernama Kerinci, Sarolangun, Bungo dan Tanjung Jabung Barat yang ditentukan secara purposive. Besar sampel sebanyak 314 petani dengan metode Simple Random Sampling. Metode analisis data menggunakan pendekatan Policy Analysis Matrix (PAM). Hasil penelitian menunjukkan bahwa usahatani padi memiliki daya saing yang tinggi. Kenaikan harga input produksi tidak mempengaruhi penurunan daya saing. Kenaikan harga gabah mengakibatkan semakin menguntungkan.
\end{abstract}

Kata kunci: Daya saing, Perbandingan, PAM, Skenario kebijakan

\section{INTRODUCTION}

National food procurement challenges ahead will be more severe, due to the high rate of population increase and the high rate of conversion of paddy fields for non agriculture. In Indonesia, from year 2011- 2017 the number of rice consumption per capita is $97.2 \mathrm{~kg}$ per year and in this period rice consumption decreased by $0.12 \mathrm{~kg}$ per capita per year (Central Bureau of Statistics, b, 2018).

In 2015, Indonesia's rice import volume reached 861.63 thousand tons, mostly came from Vietnam as much as 509.37 thousand tons with a share of $59.12 \%$ with a trade value of 202.56 million US \$. Indonesia's second-largest rice imports from Pakistan, which is 180.10 thousand tons or $20.90 \%$ share with a trading value of 62.95 million US \$, In 
addition to the two ASEAN countries, rice imports also come from Thailand with a volume of 126.75 thousand ton or $14.71 \%$ share with a trading value of 66.77 million US \$. Besides Indonesia also imports rice from India and Myanmar respectively 34.16 thousand tons and 8.78 tons with a trade value of US \$ 13.67 million and 2.73 million US \$. In 2016 the volume of imports of Indonesian rice 1:07 million tons, an increase of $24.62 \%$ from 2015 (Central Bureau of Statistics, c. 2016).

Jambi province ranks as the 19th largest contributor to the national paddy from 34 provinces in Indonesia. Jambi Province seeking paddy rice was quite spacious but extensive development and production fluctuating harvest paddy rice harvested area in Jambi province has decreased from year 2013-2015 and its production was as much as 485989 tonnes per year. Productivity of paddy rice in Jambi Province from 2011-2017 year is 4.354 tons ha-1 (Badan Pusat Statistik, a. 2018). Meanwhile rice productivity in Indonesia.mencapai 7 ton ha ${ }^{-1}$ (Hasibuan, 2015).

Measurement of the competitiveness of farming is carried out to measure the ability of a farm commodities to generate profit if the benefit of a commodity increases, it means that competitiveness is also increasing. A commodity has competitive edge if the farm is able to maintain profitability and market share. Competitiveness factors consist of technology, productivity, input, and the cost and demand conditions. Rice farming is not considered to be competitive and less profitable because the high cost of production inputs purchased is not balanced with the price of the output produced.In an increasingly competitive situation, the farm must be able to produce in sufficient quantities, sustainable, quality and profitability of private and social. If not, then the rice farming will be abandoned by the farmers and they will move on to more productive farming.

\section{METHOD}

The location study was taken in Jambi province with the sample area of Kerinci, Bungo, Sarolangun Tanjung Jabung Barat taken purposively with consideration that the area is a center of rice production and has the irrigation channel. The data consists of primary data and secondary data. Primer Data was obtained from rice farmers directly using the survey method. The sample size was determined based on the total of 314 respondents Slovin method, the distribution of samples of Table 1.

Table 1. Distribution of Total Sample Farmers Respondents

\begin{tabular}{|c|c|c|c|c|c|}
\hline No. & Districts & Sample village & Total KK & $\begin{array}{c}\text { Number of } \\
\text { samples }\end{array}$ & Percentage (\%) \\
\hline \multirow[t]{4}{*}{1} & \multirow[t]{4}{*}{ Kerinci } & 1. Semerap & 410 & 21 & 6.68 \\
\hline & & 2. Koto Dian & 365 & 19 & 6.05 \\
\hline & & 3. Benik & 346 & 18 & 5.73 \\
\hline & & 4. Kumun & 428 & 22 & 7.00 \\
\hline \multirow[t]{4}{*}{2} & \multirow[t]{4}{*}{ Bungo } & 1.Teluk Pandak & 380 & 20 & 6,38 \\
\hline & & 2. Temple & 366 & 19 & 6.05 \\
\hline & & 3. Gulf Nyiur & 398 & 21 & 6.68 \\
\hline & & 4. Pedukun & 360 & 19 & 6.05 \\
\hline \multirow[t]{4}{*}{3} & \multirow{4}{*}{ Sarolangun } & 1. Pelawan & 420 & 22 & 7.00 \\
\hline & & 2. Water Black & 318 & 17 & 5.42 \\
\hline & & 3. pelayang & 330 & 17 & 5.42 \\
\hline & & 4. Island Aro & 355 & 19 & 6.05 \\
\hline \multirow[t]{3}{*}{4} & Tanjung & 1. Sri Agung & 765 & 40 & 12.73 \\
\hline & Barat & 2. Rawamedang & 770 & 40 & 12.76 \\
\hline & Amount & & 6011 & 314 & 100 \\
\hline
\end{tabular}

Source: Data processed, 2020 
Data analysis used PAM (Policy Analysis Matrix). PAM measure private profit (actual price) and the social (efficiency). This method shows the revenues, costs, and the actual benefit derived, and compared with the values in the absence of commodities and resources are calculated at the level of international prices or Domestic Opportunity Cost. Variable farming in PAM analysis is divided into two types: variable tradeable and nontradeable variables Table 2

Table 2. Input-output tradeable and non-tradeable rice

\begin{tabular}{|c|c|c|}
\hline Input/Output & Tradeable & Non-tradeable \\
\hline Seed & - & $\sqrt{ }$ \\
\hline Urea fertilizer $(\mathrm{kg} / \mathrm{ha})$ & $\checkmark$ & - \\
\hline $\mathrm{ZA}$ & $\checkmark$ & - \\
\hline SP36 & $\checkmark$ & - \\
\hline Fertilizer $\mathrm{KCl}$ & $\checkmark$ & - \\
\hline TSP & $\checkmark$ & \\
\hline Organic fertilizer & $\checkmark$ & \\
\hline Drugs & - & $\sqrt{ }$ \\
\hline Labor & - & $\sqrt{ }$ \\
\hline Capital & & \\
\hline Working capital & - & $\sqrt{ }$ \\
\hline Land & - & $\sqrt{ }$ \\
\hline Output & $\sqrt{ }$ & - \\
\hline
\end{tabular}

Source: Ministry of Agriculture, Base Export - Import 2014 - 2015

Input prices and the price of rice use private and social price. Private prices (market price) is the actual prices that are issued and accepted by farmer. Meanswhile social prices (efficiency) is the price that must be paid by farmers in the absence of government policy. Social prices for tradable input and output is the international price for similar goods (compareable), import prices for commodity imports, export prices for export commodities. Therefore the international price is determined by the parity import / export commodities. Tradeable input costs are calculated using the social costs when importing / exporting the tradeable input.

The social price (efficiency price) and domestic factors (land, labor, and capital) are estimated using social opportunity cost, which is estimated through observations on areas studied. The goal is to determine how much revenue which is lost because of the domestic factors that are used to produce these commodities compared to if used for its best alternative commodities (Pearson, et al., 2015)

\section{Competitiveness analysis}

Competitiveness analysis used PAM (Monke, and Pearson, 1995). Policy Analysis Matrix model calculations can be seen Table 3.

Table 3. Policy analysis matrix

\begin{tabular}{|c|c|c|c|c|c|}
\hline \multirow[t]{2}{*}{ No. } & \multirow[t]{2}{*}{ commentary } & \multirow[t]{2}{*}{ Reception } & \multicolumn{2}{|r|}{ Cost } & \multirow{2}{*}{$\begin{array}{l}\text { prof } \\
\text { it }\end{array}$} \\
\hline & & & tradeable & Non-tradeable & \\
\hline 1 & Private prices & A & B & $\mathrm{C}$ & $\mathrm{D}$ \\
\hline 2 & Social price & $\mathrm{E}$ & $\mathrm{F}$ & G & $\mathrm{H}$ \\
\hline 3 & Effects difergensi & I & $\mathrm{J}$ & $\mathrm{K}$ & $\mathrm{L}$ \\
\hline
\end{tabular}

Source: Monke and Pearson, 1995, Agustian, A et al 2014. 


\section{Information :}

Profitabilitas keuangan (D)

$$
\begin{aligned}
& =\mathrm{A}-(\mathrm{B}+\mathrm{C}) \\
& =\mathrm{E}-(\mathrm{F}+\mathrm{G}) \\
& =\mathrm{A}-\mathrm{E} \\
& =\mathrm{B}-\mathrm{F} \\
& =\mathrm{C}-\mathrm{G} \\
& =\mathrm{I}-(\mathrm{K}+\mathrm{J}) \\
& =\mathrm{C} /(\mathrm{A}-\mathrm{B}) \\
& =\mathrm{G} /(\mathrm{E}-\mathrm{F}) \\
& =\mathrm{A} / \mathrm{E} \\
& =\mathrm{B} / \mathrm{F} \\
& =(\mathrm{A}-\mathrm{B}) /(\mathrm{E}-\mathrm{F}) \\
& =\mathrm{D} / \mathrm{H} \\
& =\mathrm{L} / \mathrm{H}
\end{aligned}
$$

The first row of the PAM is the calculation of the private price or financial price, the actual price received or paid by buyer-seller. Second row is a calculation that is based on social price (shadow price), the price of which describes the social value or the value of the real economy for the cost elements and results. The third row is referred to as effect line of divergence which is the difference in the calculation of the price of private from social prices as a result of the impact of government policies or existing market distortions

\section{Analysis of comparative advantage and competitive advantage}

\section{Domestic resource cost ratio (DRCR)}

Is an indicator of comparative advantage, which indicates the amount of domestic resources that can be saved to produce one unit of foreign exchange. The system has a comparative advantage if $\mathrm{DRC}<1$, and if $\mathrm{DRC}>1$ does not have a comparative advantage.

\section{Private cost ratio (PCR)}

Is a private profitability indicator that shows the ability of a commodity system to pay domestic resource costs and remain competitive. If $\mathrm{PCR}<1$, meaning a system has the advantage kompettitif commodity and if PCR $>1$ means that commodities do not have a competitive advantage.

\section{The impact of government policy}

\section{Output policy}

Transfer otput(OT) is-gap between revenue calculated on the price of financial (private) with a reception which is calculated based on the shadow price or social. If OT>0 indicates that there is a transfer from consumers to producers, and vice versa.

Nominal Protection Coefficient Output(NPCO) is an indicator that shows the level of government protection against domestic rice output. Protective policies on output happends if the value NPCO $>1$, and vice versa policies are disincentives if NPCO $<1$.

\section{Input policy}

Transfer input: $\mathrm{TI}=\mathrm{B}-\mathrm{F}$ : is the difference between the cost of inputs that can be traded in private at a price that can be traded with a social price. If the IT value $>0$, indicats that their transfer from farmers to manufacturers is tradeable input, and vice versa. 
Nominal Protection Coefficient On Input(NPCI), is an indicator that shows the government protection against domestic input prices. Policies are protective against input if the value NPCI <1, which means no subsidy policy towards tradeable input, and vice versa.

Transfer Factor (FT), is a value indicating the difference of the private price and social price received by farmers FT value> 0 means that there is a transfer of growers to producers of non-tradable inputs, and vice versa.

\section{Input -output policy-}

Effective Protection Coefficient(EPC), is an indicator that shows the simultaneous protection against input and output of tradeable. Policy will be protective if the value of the EPC> 1. The larger the value, the greater the value EPC government protection against domestic agricultural commodities.

Net Transfer(NT), is the difference between the net benefits actually received by the farmer with the social net profit. NT value> 0 , present additional surplus of farmers caused by the government's policy on the input and output, and vice versa.

Profitability Coefficient(PC), is the ratio between the net benefits actually received by the farmer by nature social advantage. If $\mathrm{PC}>0$, means that overall government policy to provide incentives to farmers, and vice versa.

Subsidy Ratio To Producer (SRP), is an indicator that shows the proportion of acceptance on the necessary social price if subsidies or tax is used as a substitute for policy.

\section{RESULTS AND DISCUSSION}

Once the data were acquired and processed, then the data is categorized bassed on its components and arranged in a matrix form. The matrix form was composed of private budget and social budget for each of the input tradeable prices, the prices of non-tradeable input and output prices. The difference of both price is called the divergence of which is the impact of government policy and market distortions in input and output that are shown in Table 4.

Table 4. Policy analysis matrix rice Jambi Province, 2018

\begin{tabular}{llrrr}
\hline \multirow{2}{*}{ Commentary } & \multirow{2}{*}{ Reception } & \multicolumn{2}{c}{ Input costs } & \multirow{2}{*}{ Profit } \\
\cline { 3 - 4 } & \multicolumn{1}{c}{ Tradeable } & Non-tradeable & \\
\hline Privat & $24,206,000.00$ & $859,850.00$ & $10,345,255.65$ & $13,000,894.35$ \\
Social & $21,463,221.50$ & $1,169,069.36$ & $11,064,775.25$ & 9.229 .376 .89 \\
divergences & $2,742,778.50$ & $-309,219.36$ & $-719,519.60$ & $3,771,517.46$ \\
\hline
\end{tabular}

Source: Data processed, 2020

Table 4 shows that the first line is the value that is calculated based on the price of the private (the actual price in the market). The second line shows the values calculated based on social price (the price that will yield the best allocation of resources). Social profitability of farming has a smaller value than the private profit. Smaller social acceptance for social paddy output prices is lower than private rates apply. The third line is called effect of

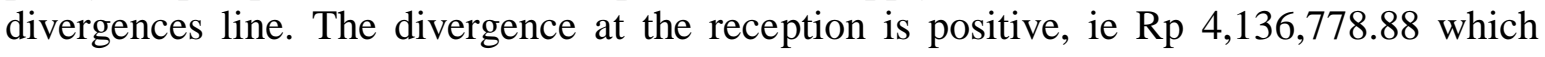
means the price of rice by farmers as they arrive actually higher than the social price that should be accepted. The policy rice import cost of Rp $450 \mathrm{~kg}-1$ set by the government in 
Permenkeu Decree No. 85 / PMK. 010/2016 implicitly pose to farm subsidies for the import tariff causing output prices higher than the price without the policy. A divergence in input costs means that there is a negative worth of rice farming after the transfer to the emerging government policies in the form of fertilizer subsidies contained in the Regulation of Decree No. 660 / Permentan / SR.130 / 12/2015 so that farmers do not pay the full amount to buy these inputs.

\section{Comparative advantage and competitive advantage}

$\mathrm{DRCR}=0.5303<1$ means that to generate one unit of value for rice at social prices requires only domestic resources amounted to $53.03 \%$ or provide economic value added (social price) of 0.5303 rupiah. Research Agustian, et al (2014) said that rice farming efficient with DRCR <1, meaning that domestic resources should be sacrificed to save or to earn foreign rice system that is smaller than the domestic resources that is available in the overall economic system.

PCR value $=0.4107<1$ shows the rice paddy farming is financially efficient and have a competitive advantage or can compete both in domestic and international markets. 0.4107 value means that to generate one unit of value-added output in private requires only domestic resources amounted to $41.07 \%$. If $\mathrm{Rp} 10$ production generated, it will provide value-added financial (private prices) amounted to $\mathrm{Rp} 4.11$. The positive value of private

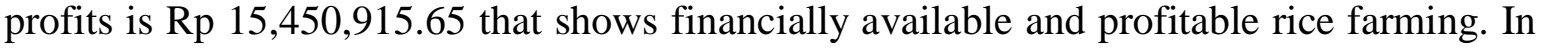
line with research conducted by Neyatri (2015) that the value of organic rice farming PCR of 0.275 , means to generate one unit of value-added output in private requires only domestic resources amounted to $27.5 \%$ (Rp.0,275).

\section{Sensitivity analysis}

The impact of the increase of fertilizer price on comparative and competitive advantages of rice farming does not affect too real because fertilizer inputs is not a quality control aspect of this farm. The increase in the price of fertilizer is by $25 \%$ and $50 \%$ of the initial price indicators resulted DRCR changed each by 0.0316 and 0.0639 from early indicator value. DRCR $<1$ indicate that paddy rice farming is still profitable economically and PCR indicator turns each by 0.0161 and 0.0324 . PCR value $<1$ indicates that rice farming is still financially beneficial in case of rise in price of urea, $\mathrm{KCl}$ andSP $\mathrm{P}_{36}$ by $25 \%$ and $50 \%$ of the starting price of fertilizer which has been purchased by the farmer.

Indicators of comparative and competitive advantages influenced paddy rice price increase. Based on Badan Pusat Statistik, the spike in inflation was caused by commodity rice contributed $0.24 \%$ to inflation in January 2018. The DRCR value before the price increase of rice amounting is 0.5303 , after the rice price increase of $0.24 \%$ resulted DRCR unchanged at 0.0013 of the initial value that becomes 0.5290 . PCR value before the price increase of rice is equal to 0.4107 , after the rice price increase of $0.24 \%$ caused PCR value unchanged at 0.0010 from an initial value that becomes 0.4097. During January 2017 January 2018, output prices rose by $6.36 \%$ then DRCR unchanged at 0,033 of the initial value becomes 0.4973 , meaning that rice farming is comparatively more superior.

\section{Government policies against Rice}

Government policy can be seen from the ratio of calculated based component PAM table, Table 5: 
Table 5. Ratio of government policy indicators against rice Jambi Province 2018

\begin{tabular}{lr}
\hline Indikator & Skor \\
\hline Privat profitability = ABC & $15,450,915.65$ \\
Social profitability = EFG & $10,219,782.52$ \\
Transfer output $(\mathrm{TO})=\mathrm{AE}$ & $4,136,778.88$ \\
Transfer input $(\mathrm{TI}) \mathrm{BF}$ & $-326,169.53$ \\
Transfer factor $(\mathrm{TF})=\mathrm{CG}$ & $-768,184.73$ \\
Transfer bersih $(\mathrm{TB})=\mathrm{DH}$ & $5,231,133.13$ \\
Private cost ratio $(\mathrm{PCR})=\mathrm{C} /(\mathrm{AB})$ & .4107 \\
Domestic resource cost ratio $(\mathrm{DRCR})=\mathrm{G} /(\mathrm{EF})$ & .5303 \\
Nominal protection coefficient outputs $(\mathrm{NPCO})=\mathrm{A} / \mathrm{E}$ & 1.1821 \\
Nominal protection coefficient on inputs $(\mathrm{NPCI})=\mathrm{B} / \mathrm{F}$ & 0.66061818 \\
Effective protection coefficient $(\mathrm{EPC})=(\mathrm{AB}) /(\mathrm{EF})$ & 1.2051 \\
Profitability coefficient $(\mathrm{PC})=\mathrm{D} / \mathrm{H}$ & 1.51 \\
Subsidy ratio to producers $=\mathrm{L} / \mathrm{E}$ & 0.23 \\
\hline
\end{tabular}

Sumber Data diolah, 2020

\section{Output policy}

\section{Transfer output}

TO value $=$ Rp.2,7 million $>0$. This value indicates that there is a transfer from the public (consumers) to farmers for Rp.2,7 million due to price differences of private price with social price. This causes the actual income earned by rice farmings which is larger than sosial income. The income price actually received by the farming is higher than the social price that should be accepted, and it leads to the decreaseing of consumer surplus and the invreasing of surplus farm. Rice import cost of Rp $450 \mathrm{~kg}-1$ resultes in implicit subsidies to rice production because the price of rice import cost is higher than the price without the policy. TO value $>0$, indicates that farmers receive incentives from consumers or producers receive a higher selling price of the social price.

\section{Nominal protection coefficient on output (NPCO)}

$\mathrm{NPCO}$ value $=1.18>1$ means that the government's policy has been able to protect rice farming. Rice import cost policy of Rp $450 \mathrm{~kg}-1$ set by the government has been able to protect rice farming so that the value of total output is $18 \%$ higher. This is in line with peneitian Jakiyah (2016) that the value NPCO> 1, meaning organic rice farmers receive subsidies on the domestic market above its output efficiency. The government policy causes the price of farm level output is higher than the social price.

\section{Input policy}

\section{Transfer input}

Input Transfer Value (IT) rice farming is negative, which means that there is a transfer to rice farming after emerging government policies towards tradeable input Rp $326,169.53$. This happens because the rice farming pays the actual cost wich is lower than the social cost. Input transfer that has negative values shows that there is government 
subsidies to foreign inputs (tradeable), which cause the producer do not pay full to purchase these inputs. Production input subsidy policy towards tradeable is very favorable for the purchase of cheaper tradable inputs (Pratt, 2016).

\section{Nominal protection coefficient on input (NPCI)}

NPCI value $=0.66<1$, is the value of import cost and given subsidies on tradeable input. This leads to the farm just to pay $66 \%$ of the costs that should be, and in this condition there is no policy. Consistent research conducted by Mukti (2013) states that the value NPCI $=0.577<1$, indicates that there is a subsidy to input farmer that caused the financial input prices which is lower than the price of its shadow.

\section{Transfer factor (TF)}

Negative value Transfer Factor rice farming negative indicates that there is negative subsidy from government to non-tradeable inputs in rice farming. This research is in line with Husaini (2012) who states that the value of transfer factor that is less than one and negative means there have been no government policy applied to non-tradeable inputs that aimed at protecting the input producers.

\section{Input-output policy}

\section{Net transfer (NT)}

Net Value Transfer rice farming Rp 5,231,133.13, means the net transfers received by rice farming after emerging government policies. NT value of Rp 5,231,133.13 is additional surplus farming (producer) as a result of government policies applied at the input-output. NT on rice farming value is positive, and it means that farmers get benefit as a result of government policies that have been applied to the input and output.

\section{Effective protection coeffecient (EPC)}

Value Effective Protection Coefficient (EPC) EPC rice farming $=1.20>1$ means the government is able to provide additional protection of the value of income received by farmers by $20 \%$ higher than it would be without policy. Policies implemented by the government in the input-output farming provides insensif for rice farmers to keep producing. Along with a research conducted by Nurayati (2015) found that the value of EPC> 1 indicates that policies that protect domestick producers works effectively. This is caused by the foreign input prices paid by farmers in line with the selling price of the output.

\section{Profitability coefficient (PC)}

Value profitability coefficient $(\mathrm{PC})=1.51>1$ means that private paddy profits is 1.51 greater than the social benefits. In line with research conducted by Salam (2016) said that the value of the PC> 1, that means the whole policy of the intensif government to farmers where the benefit received by farmers is greater than when there is no policy.

\section{Subsidy ratio to producers (SRP)}

Value SRP $=0.23>0$ means that the divergence between financial and economic advantage in rice farming around $23 \%$ of gross provit. The amount of positive transfer shows that the distortion of the market provides beneficial effects for rice farmers, because 
of the subsidy by the government. In line with research conducted Judge (2014) that if the SRP is positive, then the government needs to provide support for the farmers so their out come costs less than the social costs.

\section{CONCLUSIONS AND POLICY IMPLICATIONS}

The results showed that paddy rice farming competitiveness by PCR and DRCR value $<1$. The value of $\mathrm{PCR}=0.4107$ and $\mathrm{DRCR}=0.5303$. At the time whene there is a change in fertilizer prices by $25 \%$ and $50 \%$, it did not greatly affect the value of the PCR and DRCR. At the time of the price increase in output on the basis of inflation of $0.24 \%$ and is based on rat average output prices from January 2017 to January 2018, there is an increase amounted to $6.36 \%$ in rice paddy farming that cause rice farming is getting more profitable competitively and comparatively. Government policy, at this time as a whole, gives good impact for the farmers, which means the existing policy on input and output prices protects the domestic farmers (producers). Policy recommendations that are needed are (1) estabilishing an agency/ institute that will handle the input supply so the farmers can be easier to achieve the needed input, (2) giving guidance, training or workshop to the farmers especially in terms of technical production, (3) establishing and revising the irrigation system facilities, (4) upgrading the access and the availability of modality for the farmers.

\section{REFERENCES}

Agustian, Adang, et.al. (2014). Daya saing beberapa komoditas pangan strategis. badan penelitian dan pengembangan pertanian. Kementrian Pertanian: Jakarta.

Badan Pusat Statistik. (2016). Jambi dalam angka Badan Pusat Statistik Prov. Jambi. Jambi diakses dalam http://bps.go.id, Tanggal 19 April 2018, Pukul 18.30 WIB

Badan Pusat Statistik. (2018). Konsumsi beras Indonesia. Badan Pusat Statistik Nasional, diakses dalam http://bps.go.id, Tanggal 19 April 2018, Pukul 18.30 WIB

Badan Pusat Statistik. (2018). Padi Nasional. Badan Pusat Statistik Nasional, diakses dalam http://bps.go.id, Tanggal 19 April 2018, Pukul 18.30 WIB

Hakim, Amir. (2014). Daya saing usahatani padi sawah dengan sistem pengelolaan tanaman terpadu (PTT) di Provinsi Lampung. Tesis (Dipublikasikan). Pascasarjana Agribisnis Universitas Lambung: Lampung.

Hasibuan, Arfan. (2015). Swasembada Pangan atau Kesejahteraan Petani?, diakses dalam http:// Kompasiana.com, Tanggal 28 Januari 2018, Pukul 18.30 WIB

Husaini, Muhammad. (2012). Pengkajian daya saing dan dampak kebijakan terhadap usahatani padi dan jeruk lahan gambut Kabupaten Barito Kuala Kalimantan Selatan. Universitas Lampung Mangkurat: Kalimantan

Irawati, Denti Juli. Et.all. (2015). Analisis daya saing dan dampak kebijakan pemerintah terhadap komoditi padi sawah di Kecamatan Perbaugan Kabupaten Serdang Badagai. Fakultas Pertanian Universitas Sumatra Utara: Medan.

Jakiyah, Ulpah. et,al. (2016). Dampak kebijakan pemerintah terhadap usahatani beras organic di Provinsi Jawa Barat. IPB: Bogor

Monke, E.A. and S.R. Pearson. (1995). The policy analysis matrix for agricultural development. Cornell University Press: New York.

Mukti, Imam. (2013). Analisis keunggulan komparatif dan kompetitif usahatani padi semiorganik di Desa Ciburuy Kecamatan Cigombong Kabupaten Bogor.IPB: Bogor. 
Neyatri, Tirsa. dkk. (2015). Analisis daya saing dan dampak Kebijakan Terhadap Beras organik ekspor (suatu kasus gapoktan simpatik Kabupaten Tasikmalaya). Jurnal. Program Magister Ekonomi Pertanian, 3(1), 33-46

Pearson, SR., C. Gorsch, dan S. Bachri. (2005). Aplikasi policy analysis matrix pada pertanian Indonesia. Yayasan Obor Indonesia: Jakarta..

Pratama, Aditya. (2016). Daya saing, profitabilitas, dan efisiensi usahatani padi dan jagung di Indonesia. Skripsi. Universitar Airlangga: Surabaya.

Salam, Muslim.(2016). Analisis profitabilitas dan daya saing usahatani padi di Kebupaten Pinrang Sulawesi Selatan. UNHAS: Makasar.

World Bank (2017). Commodities price data, The pink sheet. Diakses http://worldbank.org, Tanggal 19 April 2018, Pukul 18.30 WIB 